\title{
Scavenger receptors and $\beta$-glucan receptors participate in the recognition of yeasts by murine macrophages
}

\author{
Szczepan Józefowski $\cdot$ Zhiping Yang • \\ Janusz Marcinkiewicz $\cdot$ Lester Kobzik
}

Received: 18 August 2011/Revised: 19 September 2011/Accepted: 26 October 2011/Published online: 25 November 2011

(C) The Author(s) 2011. This article is published with open access at Springerlink.com

\begin{abstract}
Objectives Numerous receptors have been implicated in recognition of pathogenic fungi by macrophages, including the $\beta$-glucan receptor dectin-1. The role of scavenger receptors (SRs) in anti-fungal immunity is not well characterized.

Methods We studied uptake of unopsonized Saccharomycetes cerevisiae (zymosan) and live Candida albicans yeasts as well as zymosan-stimulated $\mathrm{H}_{2} \mathrm{O}_{2}$ production in J774 macrophage-like cells and peritoneal exudate macrophages (PEMs). The role of different receptors was assessed with the use of competitive ligands, transfected cells and receptor-deficient macrophages.

Results The uptake of zymosan by untreated $\mathrm{J} 774$ cells was mediated approximately half by SRs and half by a $\beta$-glucan receptor which was distinct from dectin- 1 and not linked to stimulation of $\mathrm{H}_{2} \mathrm{O}_{2}$ production. Ligands of $\beta$-glucan receptors and of SRs also inhibited uptake of C. albicans by macrophages (J774 cells and PEMs). In macrophages pretreated with a $\mathrm{CpG}$ motif-containing oligodeoxynucleotide (CpG-ODN) the relative contribution of SRs to yeast uptake increased and that of $\beta$-glucan receptors decreased. Whereas the class A SR MARCO participated in the uptake of both zymosan and C. albicans
\end{abstract}

Responsible Editor: Graham Wallace.

S. Józefowski $(\bowtie) \cdot J$. Marcinkiewicz

Department of Immunology, Jagiellonian University Medical

College, 18 Czysta Street, 31-121 Kraków, Poland

e-mail: szjozefowski@poczta.onet.pl

Z. Yang $\cdot$ L. Kobzik

Molecular and Integrative Physiological Sciences Program, Harvard School of Public Health, 655 Huntington Avenue, Boston, MA 02115, USA by CpG-ODN-pretreated, but not untreated macrophages, the related receptor SR-A/CD204 was involved in the uptake of zymosan, but not of $C$. albicans. The reduction of zymosan-stimulated $\mathrm{H}_{2} \mathrm{O}_{2}$ production observed in DSpretreated J774 cells and in class A SRs-deficient PEMs suggest that class A SRs mediate part of this process.

Conclusions Our results revealed that SRs belong to a redundant system of receptors for yeasts. Binding of yeasts to different receptors in resting versus $\mathrm{CpG}-\mathrm{ODN}$-preexposed macrophages may differentially affect polarization of adaptive immune responses.

Keywords MARCO $\cdot$ CD204 $\cdot$ Oxidative burst

\section{Introduction}

Despite the availability of new anti-fungal drugs, infections caused by pathogenic fungi continue to constitute a serious medical problem. In particular, Candida albicans, an opportunistic fungal pathogen, is a major cause of morbidity and mortality among immunocompromised individuals [1]. Several studies have demonstrated the key roles of neutrophils and activated macrophages in controlling systemic and mucosal C. albicans infections [2,3]. These phagocytic cells utilize a diverse array of opsonindependent and -independent mechanisms to recognize C. albicans. Opsonin-independent mechanisms may be particularly important in the initial, critical phases of infection and in certain anatomical locations, such as the lung, in which opsonin levels are low.

Numerous receptors have been implicated in opsoninindependent recognition of $C$. albicans by innate immune cells, which reflects the complex structure of the cell wall of this eukaryotic organism, composed of chitin, $\beta$-glucans, 
different mannoproteins and glycolipids. Zymosan, a preparation of baker's yeasts (Saccharomycetes cerevisiae), is frequently used as a model particle in studies on the interactions between macrophages and yeasts. Receptors implicated in opsonin-independent recognition of $C$. albicans or of zymosan include complement receptor 3 (CR3, $\alpha_{\mathrm{M}} \beta_{2}$ integrin, CD11b/CD18) [4-6] and dectin-1 [7], which bind cell wall $\beta$-glucans; mannose receptor [8], DC-SIGN, and its murine homologue, SIGNR1 [9, 10], TLR2 [11], TLR4 [11, 12], CD14 [12], and galectin-3 [13], which bind mannans or other mannose-containing compounds. Involvement of some of these receptors in yeast recognition is controversial. For instance, Brown, Taylor et al. [14, 15] reported that opsonin-independent zymosan binding was unaffected by genetic CR3 deficiency or a blocking mAb against CR3, suggesting that CR3 was not the receptor mediating this activity. Also mannose receptor-deficient macrophages exhibited no defect in the phagocytic uptake of $C$. albicans, as well as resistance to $C$. albicans infection was unimpaired in mannose receptor-deficient mice [16].

There is evidence that opsonin-independent recognition of yeasts and zymosan by macrophages is mediated largely by dectin-1 [14, 17-19]. In different populations of mouse macrophages, zymosan binding was inhibited by antidectin- 1 mAb by as much as $50-80 \%[10,14,15]$. The antidectin-1 mAb produced similar inhibition of zymosan binding as $\beta$-glucans, leading the authors to conclude that dectin- 1 was the sole $\beta$-glucan receptor on macrophages $[10,14,15]$. Non-redundant function of dectin- 1 in $\beta$-glucan recognition seemed to be confirmed by the effects of dectin1 deficiency in mice. Taylor et al. [19] reported that in comparison with wild-type controls, thioglycollate-elicited peritoneal macrophages (PEMs) from dectin-1-deficient mice exhibited strongly decreased uptake $(\sim 70-80 \%$ reduction) of unopsonized zymosan and of $C$. albicans yeasts. Dectin-1 and TLR2 synergistically mediated zymosan- or live yeast-stimulated IL-12p40 and TNF- $\alpha$ production in macrophages [19-21]. However, other findings suggested that stimulation of TNF- $\alpha$ and IL-12 production by $\beta$-glucans and of IL- 10 by zymosan depended mainly on dectin-1 rather than on TLR2 [18, 22, 23]. Dectin1 seemed to mediate also most of zymosan- or C. albicans yeast-stimulated oxidative burst $[17,19,21]$ and leukotriene release from macrophages [24], independent of TLR2.

However, recognition of $C$. albicans and other fungi by macrophages seems to be a more complex process than is suggested by the above reports and may involve other receptors, in addition to dectin-1. For instance, dectin-1 interact with neither filamentous morphogens of $C$. albicans (hyphae and pseudohyphae) [17] nor primarily pathogenic fungi [25], which do not express $\beta$-glucans on their surface. Moreover, the aforementioned results of Taylor et al. [19] are contradicted by those of Saijo et al.
[18] who reported that PEMs from dectin-1-knockout mice bound $C$. albicans yeasts as efficiently as PEMs from wildtype mice. Netea et al. [26] reported that $C$. albicansstimulated cytokine production in monocytes/macrophages is mediated by three recognition systems, each of which sensing specific components of the $C$. albicans cell wall: by the mannose receptor which binds $\mathrm{N}$-linked mannosyl residues in mannoproteins, by TLR4 which binds O-linked mannosyl residues and, to a lesser extent, by a $\beta$-glucan receptor. Yet another receptor, galectin-3, has been suggested to mediate discrimination between $C$. albicans and $S$. cerevisiae yeasts, by binding to $\beta$-1,2-mannosides, which are expressed on the surface of $C$. albicans but not on S. cerevisiae [13].

The class A scavenger receptors, SR-A and MARCO, fulfill an important role in antibacterial host defense, as indicated by their ability to mediate phagocytosis of both Gram-positive and Gram-negative bacteria [27, 28] and by the decreased resistance to bacterial infections in mice deficient in these receptors [28-30]. Scavenger receptors were not originally considered to be involved in anti-fungal defense [27]; however, later work indicated that this presumption was incorrect [31, 32]. For example, Bin et al. [31] reported that MARCO mediated phagocytosis of yeasts opsonized with uteroglobulin-related protein 1 and other reports suggested that receptors with SR features might be involved in direct (opsonin-independent) recognition of major constituents of fungal cell walls. Dushkin et al. [33] and Vereschagin et al. [34] reported that carboxymethylated glucans were bound to mouse peritoneal macrophages via SRs. It was subsequently reported that glucans bound to two types of receptors with the features of SRs (e.g., binding acetylated low density lipoproteins and polyinosinic acid, but not polycytidylic acid) in membranes isolated from human promonocytic U937 cells. While glucan phosphate bound to both receptors, carboxymethylated glucans and a neutral $\beta$-glucan, laminarin, interacted with only one of these binding sites [35]. Zymosan was found to be a ligand of scavenger receptor with C-type lectin domain (SR-CL), a receptor structurally similar to SR-A. Like SR-A, SR-CL contains coiled-coil and collagenous domains, but the terminal scavenger receptor cysteine-rich domain (SRCR) present in SR-A is replaced by the C-type lectin domain in SR-CL. Zymosan binding to SR-CL was mediated by its collagenous domain and inhibited by polyanionic ligands of SRs [36]. When this paper was in preparation, Wang and Chandawarkar [37] reported that transfection with SR-A conferred on $\mathrm{CHO}$ cells the ability to bind zymosan.

In the presented study we have undertaken a comprehensive analysis of murine macrophage receptors involved in the uptake of zymosan and live $C$. albicans yeasts, and in zymosan-stimulated $\mathrm{H}_{2} \mathrm{O}_{2}$ production. 


\section{Materials and methods}

\section{Reagents}

Rat anti-mouse SR-A 2F8 mAb, anti-MARCO ED31 mAb and anti-dectin-1 2A11 mAb were purchased from Serotec (Oxford, UK). Rat anti-mouse CD11b mAb (clone M1/70); and the control mAbs, rat IgG2b (clone A95-1) and IgG1 (clone R3-34) were purchased from PharMingen (San Diego, CA). Horse radish peroxidase (HRP)-conjugated $\mathrm{F}(\mathrm{ab})_{2}$ fragment of goat anti-rat IgG antibody was from Rockland (Gilbertsville, PA). Alexa Fluor 488-labeled zymosan, BODIPY-labeled Staphylococcus aureus bioparticles, and carboxyl-modified $1 \mu \mathrm{m}$ fluorescent (green) polystyrene spheres were from Molecular Probes (Eugene, OR). Nuclease-resistant phosphorothioate oligonuleotide 1826, containing two mouse-optimized immunostimulatory CpG motifs (CpG-ODN: TCCATGACGTTCCTGACGTT) was obtained from Coley Pharmaceutical Group (Wellesley, MA) and recombinant mouse IFN- $\gamma$ from R\&D Systems (Minneapolis, MN). All chemical reagents not otherwise specified were obtained from Sigma Chemical Co. (St. Louis, MO).

Cells

Candida albicans yeasts expressing green fluorescent protein (GFP) were kindly donated by Dr. Cheryl A. Gale (University of Minnesota, Minneapolis, MN). Yeasts were maintained on YPD agar (Difco, Detroit, MI) in sterile Petri dishes at $4^{\circ} \mathrm{C}$. Before the experiments, yeast cells were transferred onto fresh YPD agar and incubated for 2 days at room temperature. Just before use in experiments, yeast cells were recovered, washed with sterile PBS, resuspended with a small volume of PBS, counted, and adjusted to an appropriate density with medium.

The culture of J774A.1 macrophage-like cells was maintained in FCS-RPMI medium [RPMI-1640 medium with $25 \mathrm{mM}$ HEPES, supplemented with $10 \%$ FCS (Gemini Bio-Products, Woodland, CA), $2 \mathrm{mM}$ L-glutamine, and antibiotics], in unmodified polystyrene (bacteriological grade) 6-well plates. The medium was replaced every 2-3 days. Cells, which adhere loosely under these conditions, were detached by pipetting, re-suspended in fresh medium (with or without $10 \mu \mathrm{g} / \mathrm{ml} \mathrm{CpG-ODN} \mathrm{or} 20 \mathrm{ng} / \mathrm{ml}$ IFN- $\gamma$ ) and plated at $1 \times 10^{5} /$ well in 96-well tissue culture plates, 1 day before use in experiments.

MARCO-deficient mice, developed by Soininen [30], and SR-A-deficient mice [29], both on a C57BL/6 background, were maintained in our facility under pathogenfree conditions. Mice deficient in both SR-A and MARCO (dKO) were obtained by cross-breeding the single knockouts, as described previously [38]. C57BL/6 and Balb/c mice were purchased from Charles River Labs (Wilmington, MA). Female mice, 9-14 weeks old, were used in the experiments. All procedures and animal protocols used in this study were approved by an appropriate institutional review committee. Mice were euthanized by inhalation of halothane (Halocarbon Labs, River Edge, NJ). Inflammatory peritoneal cells, elicited with $1 \mathrm{ml}$ of aged, $3 \%$ thioglycollate (Difco), injected i.p. 4-5 days prior to euthanasia, were extracted into centrifuge tubes kept on ice, washed with PBS, and re-suspended in FCS-RPMI medium. These were then plated at $1.6 \times 10^{5} /$ well in 96 -well tissue culture plates. After overnight incubation, with or without $10 \mu \mathrm{g} / \mathrm{ml}$ CpG-ODN, non-adherent cells were removed by washing, and adherent macrophages (peritoneal exudate macrophages, PEMs) were used in the experiments described below.

\section{Transfection of CHO-K1 cells}

CHO-K1 cells were grown in Ham's F12 medium (Mediatech, Herndon, VA) supplemented with 10\% FCS and $20 \mu \mathrm{g} / \mathrm{ml}$ gentamicin. Expression vectors containing full length or truncated versions of human MARCO were kindly provided by Dr. Karl Tryggvason (Karolinska Institute, Sweden). MARCO was transiently transfected into $\mathrm{CHO}-$ K1 cells using FuGENE6 (Roche, Indianapolis, IN), according to the manufacturer's instructions. Briefly, cells were washed with Ham's F-12/10\% FCS (without antibiotics) while DNA/transfection reagent mix was prepared by mixing FuGENE6 and cDNA at a 9:2 ratio ( $\mu \mathrm{l} \mathrm{Fu-}$ GENE6: $\mu \mathrm{g}$ cDNA) in serum-free medium. The DNA mix was then added to the cells, which were cultured overnight before binding assays were performed.

\section{Receptor expression}

Expression of SR-A, MARCO, CR3 and dectin-1 on adherent $\mathbf{J 7 7 4}$ cells was assessed by cellular ELISA, as described previously [39]. The culture medium was replaced with $50 \mu \mathrm{l}$ of $20 \%$ mouse serum in FCS-RPMI medium and the plate placed on ice for $10 \mathrm{~min}$ pre-incubation. Cells were subsequently incubated for $40 \mathrm{~min}$ on ice with receptor-specific mAbs or the same concentrations of isotype-matched control mAbs in $100 \mu \mathrm{l}$ of $20 \%$ mouse serum [10 (A95-1, 2A11, 2F8, M1/70) or 25 (R3-34, ED31) $\mu \mathrm{g} / \mathrm{ml}$. Unbound $\mathrm{mAbs}$ were removed by washing the wells three times with ice-cold HBSS, adherent cells were then incubated for another $40 \mathrm{~min}$ with $5 \mu \mathrm{g} / \mathrm{ml}$ of HRP-conjugated $\mathrm{F}\left(\mathrm{ab}^{\prime}\right)_{2}$ fragment of goat anti-rat $\mathrm{IgG}$ antibody in $20 \%$ mouse serum. Wells were washed five times with HBSS and $0.1 \mathrm{ml}$ of TMB (Dako, Carpinteria, CA), the HRP substrate, was added to each well. The reaction was stopped with $0.1 \mathrm{ml}$ of $2 \mathrm{M} \mathrm{H}_{2} \mathrm{SO}_{4}$ and 
absorbance at $450 \mathrm{~nm}$, with a background substraction at $570 \mathrm{~nm}$, was measured in a plate reader.

Phagocytic assay

Monolayers of adherent $\mathbf{J} 774$ cells, CHO cells, or PEMs in 96-well plates were pre-incubated for $20 \mathrm{~min}$ at room temperature with $50 \mu \mathrm{l}$ of double-concentrated solutions of receptor-specific or isotype-matched control $\mathrm{mAbs}$ (final concentrations: ED31-25 $\mu \mathrm{g} / \mathrm{ml}, 2 \mathrm{~A} 11-20 \mu \mathrm{g} / \mathrm{ml}, 2 \mathrm{~F} 8$ and $\mathrm{M} 1 / 70-10 \mu \mathrm{g} / \mathrm{ml}$ ), DS, CS, mannan, laminarin (final concentration $400 \mu \mathrm{g} / \mathrm{ml})$ or CpG-ODN $(200 \mu \mathrm{g} / \mathrm{ml})$. Suspensions of latex beads $(100 \mu \mathrm{g} / \mathrm{ml})$, BODIPY-S. aureus $(25 \mu \mathrm{g} / \mathrm{ml})$, or Alexa Fluor 488-zymosan $(50 \mu \mathrm{g} / \mathrm{ml})$ fluorescent particles were added in $50 \mu \mathrm{l}$ of the medium and allowed to be phagocytosed for $1.5 \mathrm{~h}$ at $37^{\circ} \mathrm{C}$. Incubation with $C$. albicans yeasts $\left(2 \times 10^{6} /\right.$ well $)$ was performed for $40 \mathrm{~min}$ only to prevent the formation of germ tubes, which occurs during longer incubations. The wells were washed four times with HBSS and fluorescence of bound/ingested particles was measured in a fluorescence plate reader (Spectrafluor Plus, Tecan, Research Triangle Park, NC). In experiments comparing different cell populations, fluorescence values were corrected for slight differences in numbers of adherent cells, determined on the basis of lactic dehydrogenase activity in lysates of adherent cells, as described previously [40].

$\mathrm{H}_{2} \mathrm{O}_{2}$ assay

Hydrogen peroxide production was assayed by spectrofluorimetric monitoring of $\mathrm{H}_{2} \mathrm{O}_{2}$-mediated, HRP-catalyzed oxidation of nonfluorescent Amplex Red reagent (Molecular Probes) into fluorescent resorufin, as described previously [40]. Adherent PEMs or J774 cells in 96-well plates were pre-incubated for $20 \mathrm{~min}$ at room temperature with DS or laminarin $(400 \mu \mathrm{g} / \mathrm{ml})$ and then stimulated with zymosan $(50 \mu \mathrm{g} / \mathrm{ml})$ in $0.1 \mathrm{ml} \mathrm{HBSS}$, containing $50 \mu \mathrm{M}$ Amplex Red and $1 \mathrm{U} / \mathrm{ml}$ of HRP. Fluorescence (535/ $595 \mathrm{~nm}$ ) was measured for $40 \mathrm{~min}$ every $5 \mathrm{~min}$, beginning 4 min after placing a plate in the fluorescence plate reader, pre-warmed to $37^{\circ} \mathrm{C}$. Fluorescence is directly proportional to $\mathrm{H}_{2} \mathrm{O}_{2}$ concentration [40], thus the data are presented as the difference between fluorescence at the beginning and the end of the measurement.

Data analysis

All experiments were performed in 4-5 replicates and results are presented as mean \pm SEM from either several, independent experiments or from replicates obtained in a single, representative experiment. Means were compared with Student's $t$ test for single comparisons, or with
ANOVA for multiple comparisons (GraphPad Prism software, San Diego, CA). $P$ values $<0.05$ were considered to be statistically significant.

\section{Results}

Zymosan uptake by $\mathbf{J} 774$ cells is mediated by SRs and by a $\beta$-glucan receptor(s) distinct from dectin-1

Because dectin-1 has been reported to be the dominant zymosan and $C$. albicans yeasts receptor in murine macrophages, and therefore may mask involvement of other receptors, we performed initial studies in macrophage-like J774 cells, which express low levels of dectin-1 [41]. The $\beta$-glucan, laminarin, inhibited uptake of Alexa Fluor 488-labeled zymosan by $\mathrm{J} 774$ cells by $45 \pm 4.7 \%$, while the general polyanionic inhibitor of SRs, dextran sulfate (DS), reduced zymosan uptake by $50 \pm 9.8 \%$, and a combination of these ligands reduced zymosan uptake almost completely ( $90 \pm 1.7 \%)$. At the concentration used $(0.4 \mathrm{mg} / \mathrm{ml})$ laminarin and DS exerted already maximal inhibition as no further inhibition was produced by increasing their concentration (to $0.8 \mathrm{mg} / \mathrm{ml}$ ). In contrast, zymosan uptake was not affected by the $\alpha$-glucan, dextran, or by the control polyanion chondroitin sulfate (CS), which does not bind to SRs (Fig. 1a). The additive effect of the combination of DS and laminarin on zymosan uptake suggests that receptors that bind laminarin and those that bind DS are different receptors. Uptake of zymosan was also unaffected by mannan (Fig. 1a), suggesting that receptors that bind mannan, such as the mannose receptor [8], SIGNR1 [10] and galectin-3 [13], do not participate in zymosan uptake by $\mathrm{J} 774$ cells.

Experiments using blocking mAbs specific for SR-A (targeted by $2 \mathrm{~F} 8 \mathrm{mAb}$ ) or MARCO (targeted by ED31 $\mathrm{mAb}$ ) indicate that SR-A, but not MARCO, contributes to uptake of zymosan in untreated J774 cells (Fig. 1b). Zymosan uptake in $\mathrm{J} 774$ cells was also inhibited significantly by anti-CR3 mAb, M1/70 (Fig. 1b). M1/70 mAb blocks ligand binding to the lectin-like binding site on the CR3 molecule, which has been implicated in binding to unopsonized zymosan [6]. Finally, consistent with the original description of dectin-1 as a receptor expressed at the mRNA level in dendritic cells but not J774 cells [41], dectin-1 was very weakly expressed on J774 cells (Fig. 1c), and not significantly involved in zymosan uptake, as indicated by the lack of an effect of anti-dectin-1 mAb, 2A11 (Fig. 1b).

Because the zymosan uptake assay was performed in media containing serum, there was a possibility that opsonization by serum components was responsible for zymosan binding to SR-A or CR3. To establish the impact 

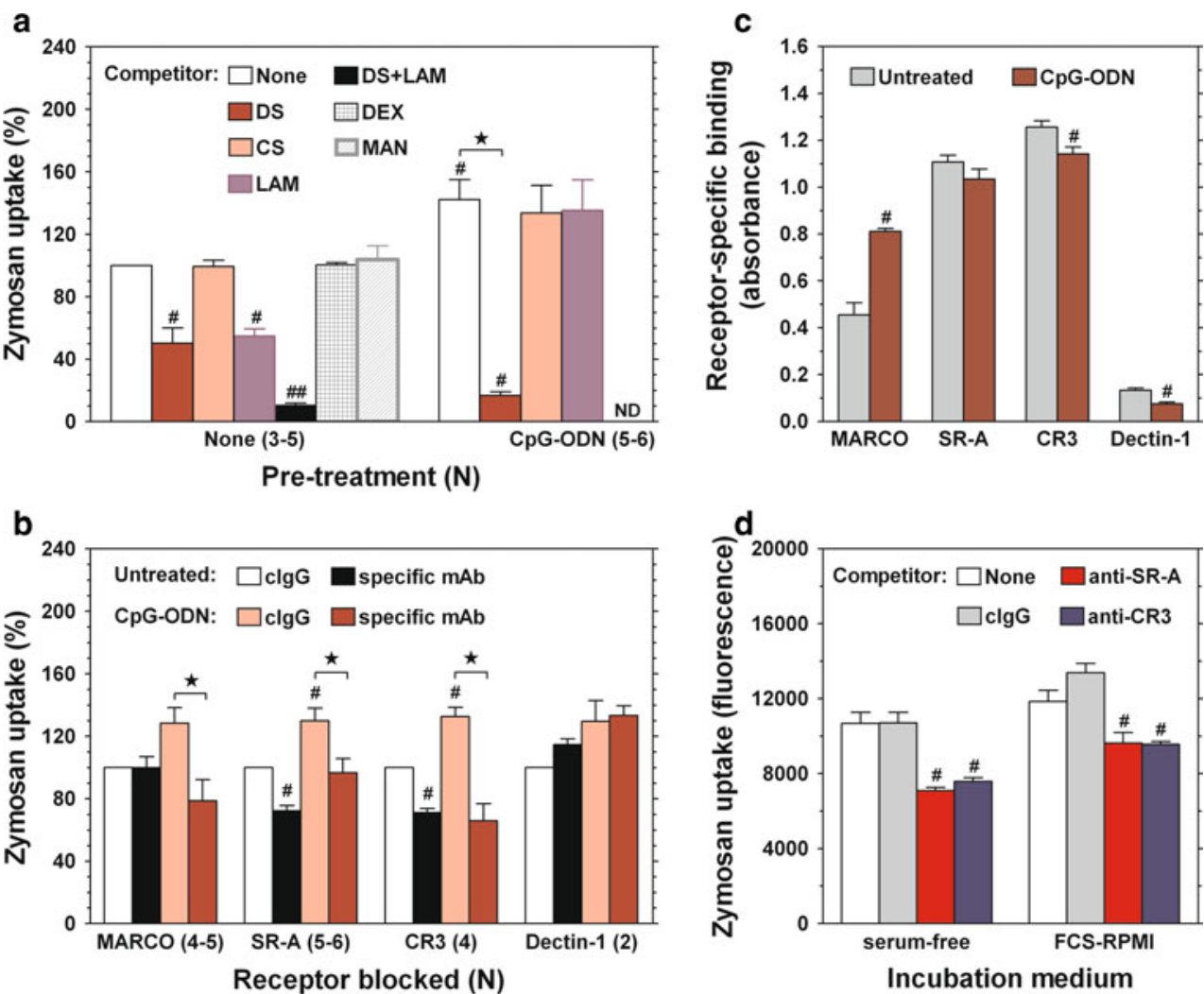

Fig. 1 Receptor specificity of zymosan uptake by untreated and CpG-ODN-pretreated J774 cells. a Untreated or CpG-ODN pretreated $\mathrm{J} 774$ cells were pre-incubated for $20 \mathrm{~min}$ at room temperature with $50 \mu \mathrm{l}$ of $0.8 \mathrm{mg} / \mathrm{ml}$ dextran sulfate (DS), chondroitin sulfate (CS), laminarin (LAM), dextran (DEX), mannan (MAN) or a combination of DS and LAM $(0.4 \mathrm{mg} / \mathrm{ml}$ each). Subsequently, a suspension of Alexa Fluor 488-labeled zymosan was added in $50 \mu \mathrm{l}$ (final concentration $50 \mu \mathrm{g} / \mathrm{ml}$ ) and allowed to be phagocytosed for $1.5 \mathrm{~h}$ at $37^{\circ} \mathrm{C}$. The wells were washed extensively and fluorescence of bound/ingested zymosan was measured in a fluorescence plate reader. b Effects of anti-MARCO $(25 \mu \mathrm{g} / \mathrm{ml})$, anti-SR-A $(10 \mu \mathrm{g} / \mathrm{ml})$, antiCR3 $(10 \mu \mathrm{g} / \mathrm{ml})$, or anti-dectin-1 $(20 \mu \mathrm{g} / \mathrm{ml})$ monoclonal antibodies, relative to effects of the same concentrations of isotype-matched control antibodies (cIgG), on zymosan uptake by untreated or $\mathrm{CpG}$ ODN pre-treated J774 cells. Cells were pre-incubated with indicated

antibodies and the zymosan uptake assay was performed as described above. c Expression of MARCO, SR-A, CR3 and dectin-1 on untreated or CpG-ODN pre-treated J774 cells which was assessed by cellular ELISA. Receptor-specific binding was calculated by subtracting the binding of isotype-matched control antibodies from the binding of receptor-specific antibodies. d Effects of indicated mAbs on zymosan uptake by untreated J774 cells in serum-free and serumcontaining media (FCS-RPMI). Data show mean $(+$ SEM) results from indicated number $(N)$ of independent experiments $(\mathbf{a}, \mathbf{b})$ or results of single experiments, each representative of two such experiments performed (c, d). Hash symbol Significantly different from untreated controls $(P<0.05$ in one-sample $t$ test $) ;$ Double hash symbol significantly different from both LAM and DS group $(P<0.05$ in two-tailed $t$ test); filled star significantly different from CpG-ODNpretreated controls $(P<0.05$ in two-tailed $t$ test $) ; N D$ not done

of serum on the results of the previous experiments, zymosan uptake in serum-free and serum-containing medium was determined. The presence of serum had no major effect on both the magnitude and the receptor specificity of zymosan uptake (Fig. 1d).

Zymosan uptake by $\beta$-glucan receptor(s) in $\mathrm{J} 774$ cells pre-treated with $\mathrm{CpG}-\mathrm{ODN}$ is decreased while that by SRs is increased

Pre-treatment with $\mathrm{CpG}-\mathrm{ODN}$ has been reported to enhance opsonin-independent phagocytosis in macrophages, largely as a result of up-regulation of SRs [39, 42]. Pre-treatment with CpG-ODN increased zymosan uptake by $\mathrm{J} 774$ cells by $47 \pm 13.4 \%(N=8, p=0.01)$ over cells with no pre-treatment (Fig. 1a), with different receptors contributing differently to the overall increase in zymosan uptake. In CpG-ODN-pretreated cells, DS alone inhibited zymosan uptake to a similar degree as the combination of DS and laminarin in untreated cells $(83 \pm 2.3 \%)$, whereas laminarin had no effect on zymosan uptake (Fig. 1a). These results indicate that SRs mediate the CpG-ODNinduced increase in zymosan uptake by J774 cells, compensating in excess decreased uptake through $\beta$-glucan receptors.

A more detailed analysis using mAbs revealed that the CpG-ODN-induced increase in zymosan uptake by $\mathrm{J} 774$ cells may be ascribed largely to MARCO; there was a 


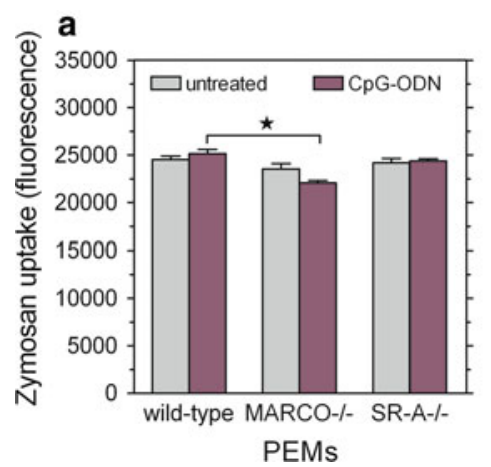

Fig. 2 Effect of class A scavenger receptors deficiencies $(\mathbf{a}, \mathbf{c})$ or anti-MARCO mAb (b) on zymosan uptake by peritoneal exudate macrophages (PEMs). Untreated or CpG-ODN pretreated PEMs, isolated from wild-type, MARCO-/-, SR-A-/- or SR-A-/MARCO-/- $(\mathrm{dKO})$ mice, were pre-incubated $(\mathbf{b})$ or not $(\mathbf{a}, \mathbf{c})$ with anti-MARCO $\mathrm{mAb}$ or the same concentration of isotype-matched control IgG1 and then co-incubated with $50 \mu \mathrm{g} / \mathrm{ml}$ zymosan

reversal of the CpG-ODN-induced increase of zymosan uptake by the anti-MARCO mAb, ED31 in these cells (Fig. 1b). Consistent with the inhibition of zymosan uptake by anti-MARCO mAb in CpG-ODN-pretreated J774 cells, these cells exhibited strongly increased levels of MARCO expression compared to untreated J774 controls (Fig. 1c), as previously reported [39]. In contrast, pre-treatment with CpG-ODN affected neither SR-A expression (Fig. 1c) nor the ability of anti-SR-A mAb to inhibit zymosan uptake (Fig. 1b). Although the CpG-ODN pre-treatment increased CR3 involvement in zymosan uptake, indicated by increased inhibitory potency of the CR3-specific mAb, M1/70 ( $29 \pm 2.8$ vs. $50 \pm 8.4 \%$ inhibition, Fig. 1b), there was slightly decreased CR3 expression on CpG-ODN pre-treated J774 cells (Fig. 1c).

SR-A or MARCO deficiency has little impact on zymosan uptake

We also assessed the role of class A SRs in zymosan uptake with the use of PEMs deficient with these receptors. The uptake of zymosan was not significantly decreased in MARCO-/- or SR-A-/- PEMs (Fig. 2a). However, CpG-ODN-pretreated MARCO-deficient PEMs exhibited slightly (by $\sim 12 \%$ ), but significantly decreased zymosan uptake in comparison to CpG-ODN-pretreated wild-type PEMs (Fig. 2a). Similarly as in J774 cells (Fig. 1b), antiMARCO antibody inhibited zymosan uptake in CpGODN-pretreated, but not in untreated wild-type PEMs (Fig. 2b). Weaker effects of receptor deficiencies as compared to receptor-specific blocking antibodies might be caused by compensatory up-regulation of alternative receptors in knockout macrophages. Indeed, we reported previously that SR-A-/- PEMs expressed increased level of MARCO [39]. Because C57BL/6 strain of mice (the parent strain of knockout mice) express an allelic isoform of SR-A which is not recognized by the available anti-SRA antibody 2F8 [43] we could not assess whether MARCO deficiency was accompanied by changes in SR-A expression. Wild-type and MARCO-/- PEMs expressed similar levels of CR3 (data not shown). In contrast, the absence of both class A SRs could not be fully compensated by alternative receptors. PEMs deficient with both SR-A and MARCO took up slightly, but significantly less zymosan than wild-type controls (by $\sim 11 \%$ ) and this difference was enhanced in CpG-ODN-pretreated macrophages $(\sim 22 \%)$ (Fig. 2c).

Uptake of zymosan and live Candida albicans yeasts is mediated by overlapping, but not identical sets of receptors

Both J774 cells (Fig. 3a, b) and PEMs (Fig. 3c) exhibited robust uptake of green fluorescent protein (GFP)-expressing live C. albicans yeasts at $37^{\circ} \mathrm{C}$. Inspection under inverted microscope revealed that the majority of $C$. albicans was trapped inside "swollen" macrophages (data not shown). J774 cells exhibited negligible binding of yeasts at $4^{\circ} \mathrm{C}$ (Fig. 3a), indicating that low temperature prevents not only internalization, but also binding of yeasts to macrophages.

The CpG-ODN pretreatment increased uptake of live yeast by $\mathrm{J} 774$ cells to a similar extent as uptake of zymosan (by $38 \pm 9.0 \%, N=6, p=0.01$, Fig. 3a, b). Similarly, effects of DS and laminarin indicate that live yeast uptake was mediated largely by $\beta$-glucan receptors in untreated $\mathrm{J} 774$ cells and by SRs, but not by $\beta$-glucan receptors, in CpG-ODN pre-treated J774 cells (Fig. 3b). A 

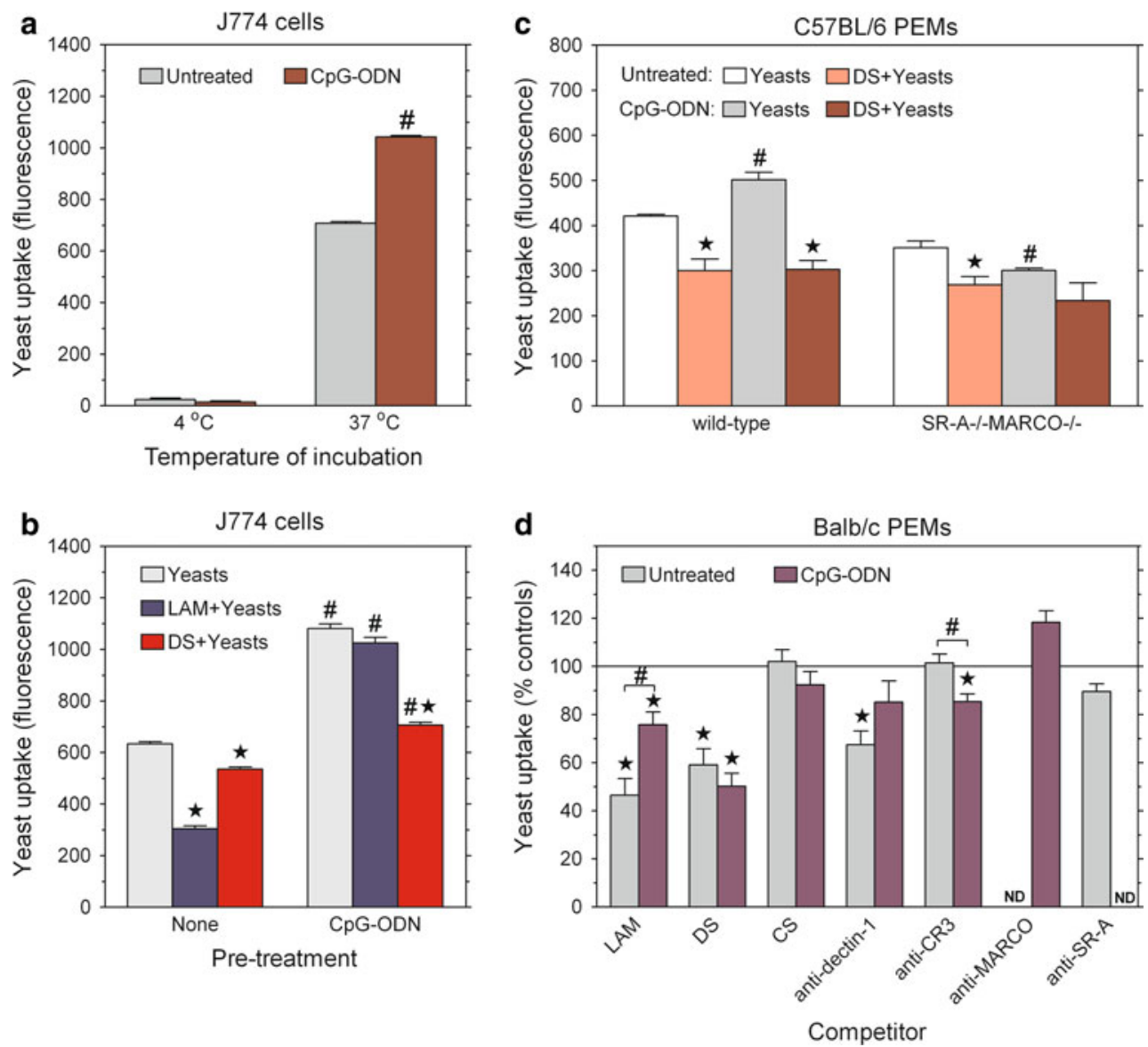

Fig. 3 Receptor specificities of live Candida albicans yeasts uptake by J774 cells and PEMs. a Untreated or CpG-ODN pre-treated J774 cells were co-incubated with C. albicans yeasts for $40 \mathrm{~min}$ at 4 or $37^{\circ} \mathrm{C}$, washed four times and fluorescence of $\mathrm{J} 774$ cells-associated yeasts was measured. b, c Effect of laminarin (LAM) and dextran sulfate (DS) on C. albicans yeasts uptake by untreated or CpG-ODN pre-treated J774 cells (b) or wild-type or SRA-/-MARCO-/PEMs (c). Macrophages were pre-incubated for $20 \mathrm{~min}$ at room temperature with LAM or DS and the yeast uptake assay was performed at $37^{\circ} \mathrm{C}$ as described above. d Receptor specificity of yeasts uptake by untreated or CpG-ODN pre-treated Balb/c PEMs.

control polyanion, CS, had no effect on yeast uptake (data not shown). However, results of experiments with the use of other competitive receptor ligands indicate that receptor specificities of zymosan and live yeasts in J774 macrophages are not identical. In particular, anti-SR-A and anti-CR3 mAbs, which inhibited zymosan uptake by untreated J774 cells (by $28 \pm 3.4 \%$ and $29 \pm 2.8 \%$, respectively, Fig. 1b) had no significant effect on live yeast uptake (data not shown). The lack of SR-A involvement in yeast uptake may explain the reduced ability of DS to inhibit live yeast uptake $(24 \pm 5.6 \%$ inhibition, $N=4, p=0.02$, Fig. $3 b$ ) as compared to zymosan uptake $(50 \pm 9.8 \%$ inhibition, $N=5$, $p=0.007$, Fig. 1a) in untreated J774 cells.
Adherent macrophages were pre-incubated with the indicated ligands for $20 \mathrm{~min}$ at room temperature before the phagocytic assay was performed in the continuous presence of these ligands. Graphs (ac) show results of single experiments, each representative of 2-4 such experiments performed. Data on graph (d) are expressed as \% of controls (no competitor or isotype-matched control $\mathrm{IgG}$ ) and are means +SEM from 3 to 7 independent experiments. Filled star significantly different $(P<0.05$ in two-tailed $t$ test $)$ from the respective control (no competitor or isotype-matched control $\mathrm{IgG}$ ); Hash symbol significant effect of the CpG-ODN pre-treatment $(P<0.05$ in two-tailed $t$ test $) ; N D$ not done

The receptor specificity of yeast uptake by PEMs was also assessed. For these studies PEMs from Balb/c mice were used because of the above mentioned inability of $2 \mathrm{~F} 8$ $\mathrm{mAb}$ to bind to an allelic isoform of SR-A which is expressed in C57BL/6 mice [43]. As with J774 cells, uptake of $C$. albicans by PEMs from Balb/c mice was inhibited by laminarin and by DS, but not by anti-SR-A mAb (Fig. 3d). C. albicans uptake by PEMs from Balb/c mice was also significantly inhibited by anti-dectin- $1 \mathrm{mAb}$ (Fig. 3d). Both laminarin and anti-dectin-1 mAb exhibited decreased ability to inhibit yeast uptake in CpG-ODN-pretreated PEMs. Conversely, anti-CR3 mAb slightly inhibited yeast uptake in $\mathrm{CpG}-\mathrm{ODN}$-pretreated, but not untreated PEMs. Mannan did not affect yeast uptake by 

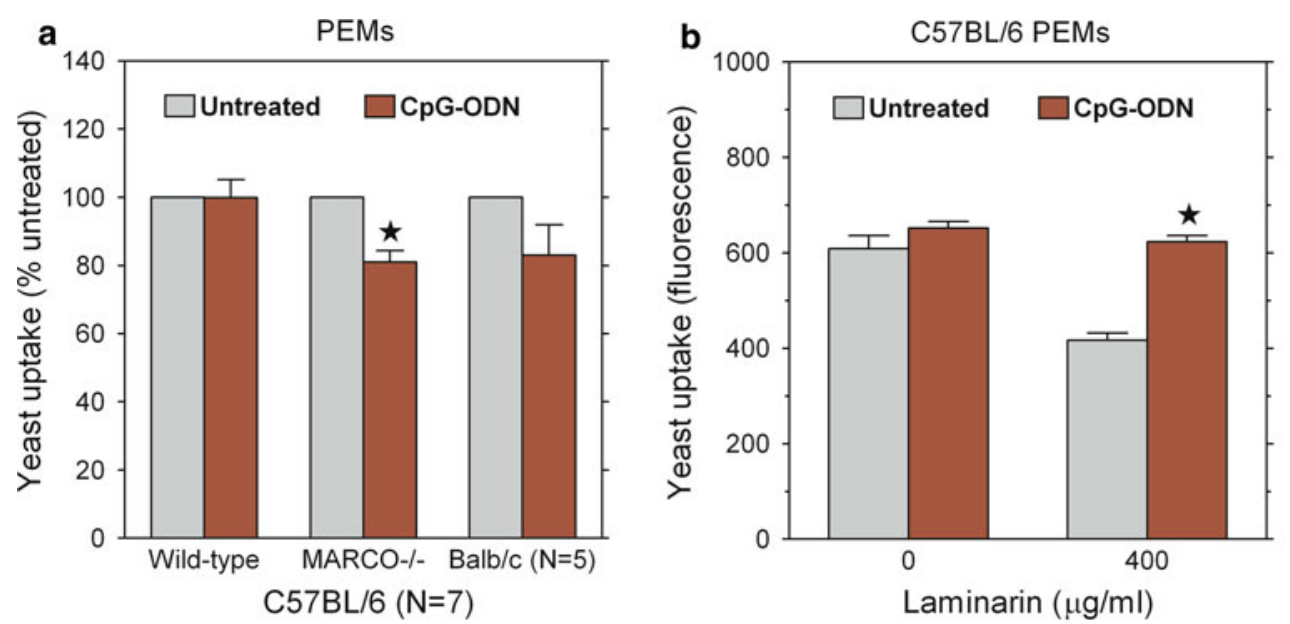

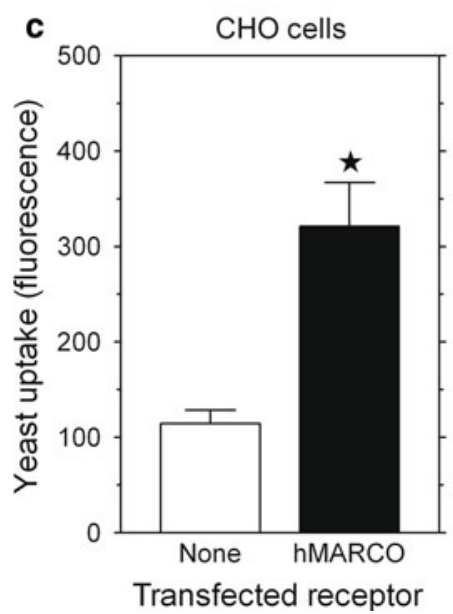

Fig. 4 Role of MARCO as a receptor for C. albicans yeasts. a The effect of CpG-ODN pre-treatment on yeasts uptake by $\mathrm{Balb} / \mathrm{c}$, wildtype or MARCO-deficient C57BL/6 PEMs. b Uptake of yeasts by untreated or CpG-ODN pre-treated wild-type PEMs, in the presence or absence of $0.4 \mathrm{mg} / \mathrm{ml}$ laminarin. c Uptake of yeasts by $\mathrm{CHO}$ cells transfected with human MARCO (hMARCO). Filled star significantly different from respective controls (untreated PEMs or nontransfected $\mathrm{CHO}$ cells $)(P<0.05$ in one-sample $(\mathbf{a})$ or two-tailed (b-c) $t$ test). d Uptake of BODIPY-labeled $S$. aureus, GFP-expressing

untreated or CpG-ODN-pretreated $\mathrm{J} 774$ cells or PEMs (data not shown).

Binding of yeasts to MARCO is mediated by a novel binding site

Neither SR-A nor MARCO deficiency had a consistent effect on yeast uptake by PEMs (data not shown). However, a difference between wild-type and MARCOdeficient strains of macrophages became apparent after CpG-ODN pre-treatment. On average from several experiments, the CpG-ODN pretreatment had no significant effect on $C$. albicans uptake by PEMs from wild-type C57BL/6 mice (in individual experiments the effect ranged
C. albicans yeasts or fluorescent polystyrene spheres by CHO cells transfected with either the full-length human MARCO (MARCO ${ }_{\text {FULL }}$ ) or with receptors with the truncated SRCR domain $\left(\mathrm{MARCO}_{442}\right.$ or $\left.\mathrm{MARCO}_{420}\right)$. Different symbols above error bars indicate values significantly different from one another $(P<0.05$, ANOVA). Data on graph (a) are expressed as \% of untreated controls and are means + SEM from indicated number $(N)$ of independent experiments. Graphs (b-d) show results of single experiments, performed in 4-5 replicates, each representative of three such experiments performed

from slight enhancement to slight inhibition), but significantly decreased yeast uptake by PEMs from MARCOdeficient C57BL/6 mice (Fig. 4a). However, although the magnitude of yeast uptake in CpG-ODN-pretreated PEMs from wild-type C57BL/6 mice did not change, the contribution of non- $\beta$-glucan receptors to yeast uptake increased, while the contribution of $\beta$-glucan receptors decreased. This is indicated by the decreased ability of laminarin to inhibit yeast uptake in CpG-ODN-pretreated as compared to untreated C57BL/6 PEMs (Fig. 4b). In regard to uptake of live yeast, the above results indicate that down-regulation of $\beta$-glucan receptors in $\mathrm{CpG}-\mathrm{ODN}$-pretreated wildtype C57BL/6 PEMs is compensated by up-regulation of other receptors which seem to include MARCO. 

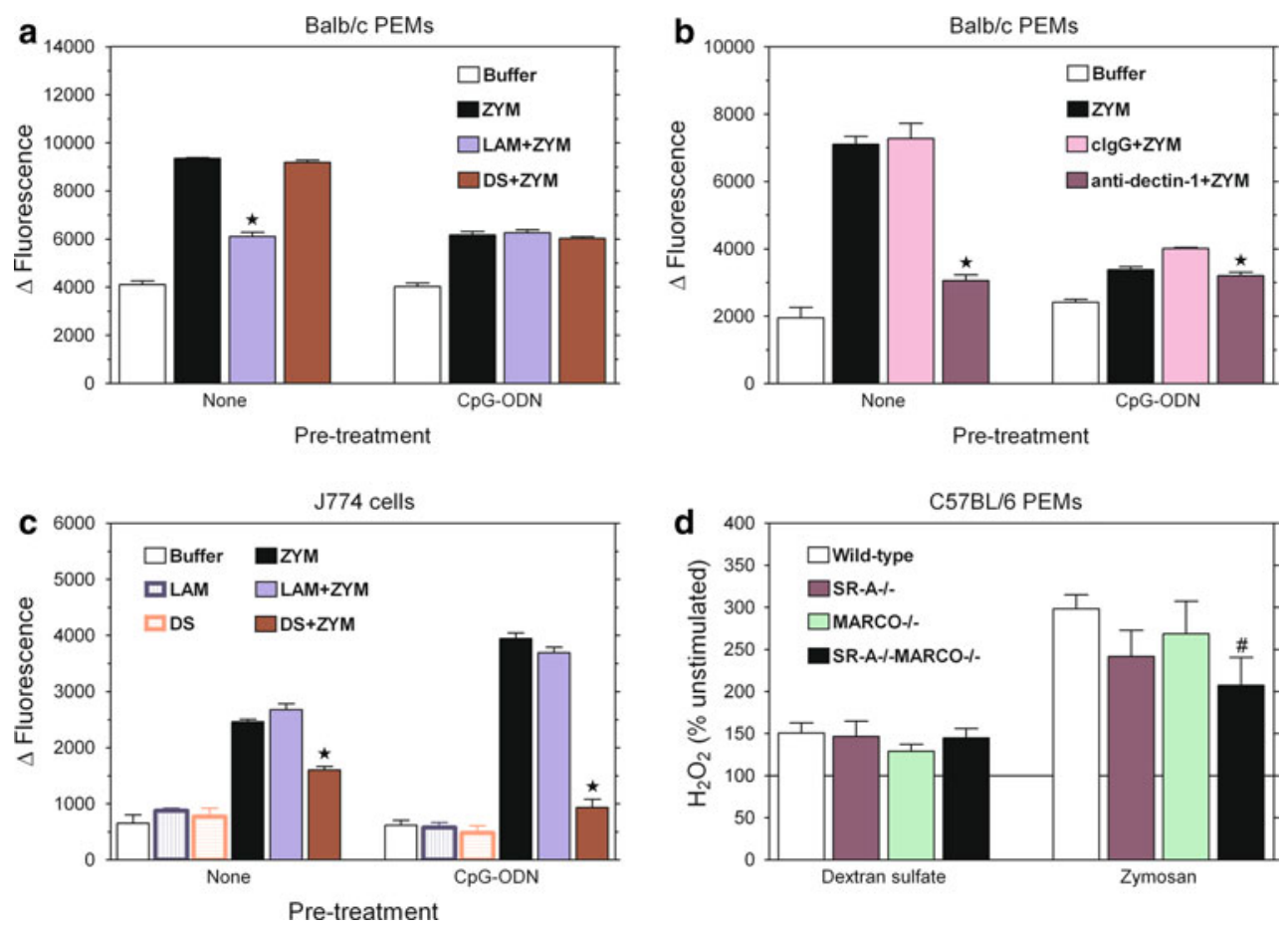

Fig. 5 Hydrogen peroxide production in untreated or CpG-ODN pre-treated macrophages exposed to dextran sulfate (DS), laminarin (LAM), anti-dectin-1 mAb, zymosan (ZYM) or combination of these ligands. a Effect of LAM or DS on ZYM-stimulated $\mathrm{H}_{2} \mathrm{O}_{2}$ production in untreated or CpG-ODN pre-treated Balb/c PEMs. b Effect of antidectin-1 mAb $2 \mathrm{~A} 11$ or isotype-matched control $\operatorname{IgG} 2 \mathrm{~b}$ (cIgG) on ZYM-stimulated $\mathrm{H}_{2} \mathrm{O}_{2}$ production in untreated or CpG-ODN pretreated Balb/c PEMs. c Effect of LAM or DS on ZYM-stimulated $\mathrm{H}_{2} \mathrm{O}_{2}$ production in untreated or CpG-ODN pre-treated $\mathrm{J} 774$ cells.

Interestingly, the effect of CpG-ODN pre-treatment on yeast uptake by Balb/c PEMs resembled that seen in MARCO-/- PEMs, although, due to high inter-experimental variability, it did not reach statistical significance (Fig. 4a). Moreover, in contrast to J774 cells (Fig. 3b) and C57BL/6 PEMs (Fig. 3c), the ability of DS to inhibit yeast uptake was not increased in CpG-ODN-pretreated PEMs from Balb/c mice (Fig. 3d). The latter results might be explained by a limited contribution of MARCO to yeast uptake by PEMs of the Balb/c strain. Unlike J774 cells and PEMs from C57BL/6 mice, PEMs from Balb/c mice express very low or undetectable level of MARCO, which is only weakly up-regulated by the CpG-ODN pretreatment [39]. Confirming such an interpretation, pretreatment with CpG-ODN did not increase potency of DS to inhibit yeast uptake also in C57BL/6 PEMs deficient with both SR-A and MARCO (Fig. 3c).

The involvement of MARCO in yeast uptake was confirmed in experiments with transfected cells. $\mathrm{CHO}$ cells transfected with human MARCO exhibited significantly increased binding of yeasts as compared to non-transfected CHO cells (Fig. 4c). Despite the apparent role of MARCO in the uptake of live yeast by macrophages, the anti-

d DS- or ZYM-stimulated $\mathrm{H}_{2} \mathrm{O}_{2}$ production by wild-type, MARCO-/-, SR-A-/- or MARCO-/-SR-A-/- PEMs. Graphs (a-c) show result of single experiments (mean + SEM), performed once (b) or representative of three such experiments performed (a and c). Results on graph (d) are means + SEM from 3 to 5 independent experiments. Asterisk symbol significantly different from the zymosan only (a and c) or zymosan plus cIgG-stimulated (b) controls $(P<0.05$ in two-tailed $t$ test); Hash symbol significant effect of receptor deficiency $(P<0.05$ in one-way ANOVA)

MARCO mAb, ED31, did not inhibit uptake of yeasts in non-treated $\mathbf{J} 774$ cells as well as in CpG-ODN-pre-treated J774 cells (data not shown) or PEMs from Balb/c mice (Fig. 3d).

The ligand binding site of SR-A is localized in the collagenous domain of the receptor [44]. In contrast, although MARCO contains a homologous collagenous domain, binding of MARCO ligands has been mapped to the SRCR domain of the receptor [45]. We hypothesized that the inability of the SRCR-directed anti-MARCO mAb, ED31, to inhibit yeast binding results from the binding of yeasts at a distinct binding site, localized outside the SRCR domain. This hypothesis was tested with the use of $\mathrm{CHO}$ cells transfected with either full-length $\left(\mathrm{MARCO}_{\mathrm{FULL}}\right)$ or truncated versions of human MARCO, lacking different peptide sequences of the SRCR domain. CHO cells transfected with MARCO $_{\text {FULL }}$ exhibited increased binding of yeasts in addition to the established MARCO ligands, polystyrene spheres and Staphylococcus aureus (Fig. 4d). In $\mathrm{CHO}$ cells transfected with $\mathrm{MARCO}_{442}$ (containing only first 22 residues of the SRCR domain of the receptor), binding of $S$. aureus was decreased and that of polystyrene spheres abolished entirely. CHO cells transfected with 
$\mathrm{MARCO}_{420}$ (lacking the entire SRCR domain) bound neither $S$. aureus nor polystyrene spheres. In contrast, there was an increase in yeast binding to $\mathrm{CHO}$ cells transfected with both forms of truncated MARCO receptors (Fig. 4d).

Different receptors mediate zymosan-stimulated $\mathrm{H}_{2} \mathrm{O}_{2}$ production in PEMs and $\mathrm{J} 774$ cells

The zymosan-stimulated oxidative burst in murine macrophages has been shown to be mediated by dectin- 1 and blocked by laminarin $[19,21]$. Confirming these reports, laminarin inhibited by $54 \pm 7.4 \%$ (average from four experiments) zymosan-stimulated $\mathrm{H}_{2} \mathrm{O}_{2}$ production by Balb/c PEMs (Fig. 5a). There was a reduction in zymosanstimulated oxidative burst in CpG-ODN-pretreated PEMs compared to untreated PEMs (Fig. 5a, b), which may be related to down-regulated dectin-1 expression/function (Figs. 1c, 3d), and as reported previously for ligands of other TLRs [46]. This hypothesis was confirmed in two out of three experiments in which laminarin produced no inhibition of zymosan-stimulated oxidative burst in CpGODN-pre-treated PEMs (Fig. 5a and data not shown). In one such experiment performed, anti-dectin- $1 \mathrm{mAb}$ inhibited most of zymosan-stimulated $\mathrm{H}_{2} \mathrm{O}_{2}$ production in untreated PEMs, but had little effect in CpG-ODN-pretreated PEMs (Fig. 5b).

In contrast to PEMs, laminarin produced no inhibition of zymosan-stimulated oxidative burst in J774 cells (Fig. 5c). These results provide further evidence that a yeast-binding $\beta$-glucan receptor(s) in $\mathbf{J} 774$ cells is distinct from dectin-1.

Zymosan-stimulated $\mathrm{H}_{2} \mathrm{O}_{2}$ production was significantly decreased in PEMs from mice lacking both SR-A and MARCO (Fig. 5d) suggesting that class A SRs may mediate part of this response. While DS inhibited zymosan-stimulated $\mathrm{H}_{2} \mathrm{O}_{2}$ production in $\mathrm{J} 774$ cells (more strongly in CpG-ODN-pre-treated than in untreated cells; Fig. 5c) but not in Balb/c PEMs (Fig. 5a), DS alone stimulated significant $\mathrm{H}_{2} \mathrm{O}_{2}$ production in PEMs from C57BL/6 (Fig. 5d) and Balb/c mice (data not shown), but not in J774 cells (Fig. 5c). Therefore, the lack of inhibition of zymosan-stimulated $\mathrm{H}_{2} \mathrm{O}_{2}$ production by $\mathrm{DS}$ in PEMs may be a net effect, resulting from any reduction of zymosan-stimulated $\mathrm{H}_{2} \mathrm{O}_{2}$ production by DS being compensated for by the significant amount of $\mathrm{H}_{2} \mathrm{O}_{2}$ production induced by DS alone, effects that seem to be mediated by different receptors. DS alone stimulated similar $\mathrm{H}_{2} \mathrm{O}_{2}$ production in PEMs from wild-type and from SR-A- or MARCO-deficient mice (Fig. 5d) indicating a lack of involvement of class A SRs in this process. Spontaneous or zymosan-stimulated production of $\mathrm{H}_{2} \mathrm{O}_{2}$ was not affected by CS in either J774 cells or PEMs (data not shown).

\section{Discussion}

Our experiments revealed that SRs participated in opsoninindependent uptake of both zymosan and live $C$. albicans yeasts by murine macrophages (J774 cells and PEMs). More specifically, we have found that SR-A is a receptor for zymosan, but not live C. albicans yeasts, and that MARCO contributes to both $C$. albicans and zymosan uptake in CpG-ODN-pre-treated macrophages.

Interestingly, the receptors involved in the uptake of yeasts and the associated biological effects differed by cell type. For example, a $\beta$-glucan receptor, dectin-1, was partially responsible for yeast uptake in PEMs but not in J774 cells. Consistent with previous findings [19, 21], dectin-1 appeared to be also the major receptor mediating zymosan-stimulated $\mathrm{H}_{2} \mathrm{O}_{2}$ production in PEMs, but in $\mathrm{J} 774$ cells, which express very low level of dectin-1, other receptors substituted for dectin-1 in mediating this response. We demonstrated that $\mathrm{H}_{2} \mathrm{O}_{2}$ production in $\mathrm{J} 774$ cells was inhibited by the SRs ligand, DS, but not by the $\beta$-glucan, laminarin. The $\beta$-glucan receptor (or receptors) in $\mathrm{J} 774$ cells that does not mediate $\mathrm{H}_{2} \mathrm{O}_{2}$ production remains to be identified. The inhibition of zymosan-stimulated $\mathrm{H}_{2} \mathrm{O}_{2}$ production by DS in $\mathrm{J} 774$ cells and the decreased zymosan-stimulated $\mathrm{H}_{2} \mathrm{O}_{2}$ production in PEMs from MARCO- and SR-A-deficient mice suggest that class A SRs mediate part of this process. Indeed, we reported previously that SR-A is able to mediate $\mathrm{H}_{2} \mathrm{O}_{2}$ production upon specific ligation with mAb [40].

Dextran sulfate produced greater inhibition of zymosan uptake in untreated $\mathbf{J} 774$ cells $(\sim 50 \%)$ than did anti-SR-A $\mathrm{mAb}(\sim 28 \%)$, suggesting that SR-A does not fully account for SRs-mediated zymosan uptake in these cells. Class A SRs also do not seem exclusively responsible for SRsmediated uptake of $C$. albicans yeasts by PEMs since DS inhibited C. albicans uptake also in PEMs from SR-A- and MARCO-deficient mice (by $\sim 24 \%$, Fig. 3c). The SRs responsible for non-class A SR-mediated, DS-inhibitable binding of zymosan and live yeast in these cells remain to be identified. A possible candidate is the scavenger receptor with C-type lectin domain (SR-CL), as this receptor is expressed in J774 cells at a high level [47] and mediates zymosan binding that is inhibited by DS [36]. Recently, two receptors from the SR superfamily, SREC-I (scavenger receptor expressed by endothelial cells-I) and CD36, were identified as receptors for fungal pathogens [48]. However, it seems unlikely that these receptors had a major contribution to zymosan or yeast uptake under our assay conditions because binding of fungi to these receptors was reported to be inhibited by both $\beta$-glucans and classical SR ligands, whereas in our study receptors inhibited by laminarin and by DS represented distinct, independently-regulated populations of receptors. 
Moreover, binding of fungi to SREC-I and CD36 was partially inhibited by mannan, which had no effect on C. albicans or zymosan uptake by $\mathrm{J} 774$ cells or PEMs in our study.

We demonstrated that anti-CR3 mAb inhibited zymosan uptake by $\mathrm{J} 774$ cells and $C$. albicans uptake by CpG-ODNpretreated, but not by untreated macrophages. Though it has been assumed that CR3 is a receptor for zymosan and more pure $\beta$-glucans [4-6], this assumption has been challenged [14, 15]. Our results suggest that although CR3 does participate in zymosan uptake, it is not a $\beta$-glucan receptor in mouse macrophages because anti-CR3 antibody inhibited zymosan or yeast uptake under conditions in which the $\beta$-glucan laminarin had no effect, and vice versa (Figs. 1a, b, 3d). Furthermore, involvement of CR3 in zymosan or yeast uptake did not correlate with CR3 expression. One possible explanation for this apparent contradiction is that CR3 does not bind yeast directly, but cooperates with other yeast-binding receptors which are up-regulated in CpG-ODN-pretreated macrophages. CR3 is known to enter into functional cooperation with several different families of receptors [49]. These CR3 interactions seem to be mediated by the lectin-like binding site of the receptor, which is blocked by the mAb, M1/70 [6]. Thus, anti-CR3 M1/70 mAb might inhibit zymosan and yeast uptake by preventing cooperation of CR3 with other receptors which bind yeasts directly.

One major methodological difference between our studies and those of Brown, Taylor et al. [14, 15] who demonstrated the lack of CR3 involvement in zymosan binding, is that we performed the zymosan uptake assay at $37^{\circ} \mathrm{C}$ instead of $4^{\circ} \mathrm{C}$. The physiological relevance of ligand binding at $4^{\circ} \mathrm{C}$ is debatable; we observed negligible binding of yeasts at this temperature. It is possible that this low, non-physiological temperature may prevent inter-receptor cooperation or receptor clustering, which may be required for multivalent, high-affinity binding of yeasts. The rationale for performing binding assays at $4^{\circ} \mathrm{C}$ was to prevent zymosan opsonization by complement components released from macrophages $[14,15]$; we found that binding of zymosan to CR3 and SRs was not mediated by opsonins present in serum or released from macrophages. Uptake of zymosan was inhibited by anti-CR3 and anti-SR-A mAbs to a similar extent in serum-free medium and in serumcontaining medium (Fig. 1d). Moreover, zymosan uptake by $\mathrm{J} 774$ cells was almost completely blocked by a combination of ligands (DS and laminarin, Fig. 1a) that are unlikely to inhibit complement-, antibody-, or mannosebinding lectin-mediated phagocytosis.

Recently, we identified MARCO as one of receptors for phosphorothioate-modified oligodeoxynucleotides (ODNs) [38]. As with yeasts, binding of ODNs to MARCO was not inhibited by ED31 mAb. Interestingly, in IFN- $\gamma$-pretreated
J774 cells, which have up-regulated MARCO expression (data not shown), CpG-ODN at $200 \mu \mathrm{g} / \mathrm{ml}$ inhibited uptake of yeasts by as much as $\sim 52 \%$ and zymosan uptake by $\sim 13 \%$, but had no effect on polystyrene sphere uptake (data not shown). Thus, yeasts and ODNs may share a novel ligand binding site on MARCO, distinct from the previously identified binding site for bacteria and polystyrene spheres in the SRCR domain, as suggested by experiments with truncated receptors (Fig. 4d). The specific ligands for SRs on the surface of yeasts remain to be identified. Ligands of class A SRs share a common property of being negatively charged [44]. In the case of C. albicans, its surface net negative charge is largely due to phosphate groups present in the cell wall phosphomannans and phospholipomannans [50, 51]. Therefore, we hypothesize that the common, specific ligands for MARCO, present on the surface of both ODN aggregates and C. albicans yeasts, may be phosphate groups.

Our another major finding is that CpG-ODN-induced macrophage activation, known to be mediated by TLR9, alters the receptors involved in yeast uptake. When compared to untreated macrophages, CpG-ODN-pretreated macrophages had reduced $\beta$-glucan receptors involvement in yeast and zymosan uptake and increased SRs involvement. For example, laminarin strongly inhibited zymosan and yeast uptake in untreated, but not in CpG-ODN-pretreated, macrophages. Conversely, anti-MARCO mAb inhibited zymosan uptake in CpG-ODN-pretreated, but not in untreated, macrophages. We found that the CpG-ODNinduced decrease in yeast uptake through $\beta$-glucan receptors was fully countered by increased uptake mediated by non- $\beta$-glucan receptors in $\mathrm{J} 774$ cells and PEMs from C57BL/6 mice, but not in PEMs from Balb/c mice. Because the $\mathrm{CpG}-\mathrm{ODN}$ pretreatment caused a significant decrease in yeast uptake by PEMs from MARCO-deficient C57BL/6 mice, this strain-related variability in CpG-ODN effects on yeast uptake might have resulted from different effects of the CpG-ODN pretreatment on MARCO expression. Indeed, the CpG-ODN pretreatment strongly up-regulated MARCO expression on J774 cells and PEMs from C57BL/6 mice, but had at most weak effect on the already much lower basal MARCO expression on PEMs from Balb/c mice [39].

Different receptors mediating yeast binding in resting versus activated macrophages are likely to differently affect macrophage immunoregulatory functions. Both Th1type and Th17-type adaptive immune responses have been implicated in successful host defense against $C$. albicans infection and their relative importance in mucosal and systemic candidiasis is a subject of ongoing debate [5254]. Our results are consistent with the possibility that during fungal infections antigen presenting cells may initiate Th17-type and Th1-type responses sequentially in, 
respectively, initial and later phases of infection. Dectin-1, which mediates phagocytosis of $C$. albicans yeasts by resting macrophages, has been reported to promote differentiation of Th17 lymphocytes and to suppress differentiation of Th1 lymphocytes, probably by inhibiting production of IL-12 and stimulating production of IL-23, IL-6 and IL-10 $[25,55,56]$. In later phases of infection, activation of endosomal TLR9 by DNA liberated from ingested and degraded C. albicans [57] would result in down-regulation of dectin-1 and up-regulation of MARCO expression on antigen presenting cells. MARCO-mediated interactions of activated antigen presenting cells with C. albicans would provide a necessary co-stimulatory signal for a TLR-mediated production of IL-12 [38, 39], a cytokine crucial for the development of Th1-type adaptive immune responses.

It was reported that zymosan generated immune tolerance in mice [58]. Interestingly, SR-A has been linked to inhibition of IL-12p70 production [39, 40] and stimulation of IL-10 secretion [59] and, therefore, might contribute to the reported suppression of adaptive immunity by zymosan [58]. As shown in this work, SR-A mediates macrophage binding of zymosan but not intact yeasts. We hypothesize that the surface of zymosan particles, with exposed $\beta$-glucan-rich inner layers of the yeast cell wall, may mimic products of fungal cell degradation by phagocytic cells. Consequently, one of functions fulfilled by SR-A might be negative feedback regulation of anti-fungal immune responses upon binding killed yeast debris. Consistent with this proposed negative regulatory role for SR-A during fungal infections, SR-A-deficient mice were reported to exhibit enhanced inflammation and elevated numbers of activated CD4+ T cells in the alveoli during lung infection with an opportunistic fungal pathogen, Pneumocystis carinii [32].

In conclusion, our results revealed that SRs and $\beta$-glucan receptors are two major receptor types involved in yeast uptake by murine macrophages and in zymosanstimulated $\mathrm{H}_{2} \mathrm{O}_{2}$ production in these cells. The relative contribution of these receptors to yeast uptake depended on the activation state of macrophages, with yeast uptake being mediated largely by $\beta$-glucan receptors in untreated macrophages and by SRs, but not $\beta$-glucan receptors, in macrophages pre-exposed to a ligand of TLR9. Experiments with the use of competitive ligands, transfected or receptor-deficient cells allowed us to identify SR-A as one of SRs responsible for uptake of zymosan, but not of live C. albicans yeasts, and MARCO as a receptor contributing to uptake of both C. albicans and zymosan in CpG-ODNpre-treated, but not untreated macrophages.

Acknowledgments This work was supported in part by the grants from Jagiellonian University Medical Collage K/ZDS/002326 and National Institutes of Health ES11008.
Open Access This article is distributed under the terms of the Creative Commons Attribution Noncommercial License which permits any noncommercial use, distribution, and reproduction in any medium, provided the original author(s) and source are credited.

\section{References}

1. Pfaller MA, Jones RN, Doern GV, Fluit AC, Verhoef J, Sader HS, Messer SA, Houston A, Coffman S, Hollis RJ. International surveillance of bloodstream infections due to Candida species in the European SENTRY Program: species distribution and antifungal susceptibility including the investigational triazole and echinocandin agents. Diagn Microbiol Infect Dis. 1999;35:19-25.

2. Van't Wout JW, Linde I, Leijh PCJ, Van Furth R. Contribution of granulocytes and monocytes to resistance against experimental disseminated Candida albicans infections. Eur J Clin Microbiol Infect Dis. 1988;7:736-41.

3. Vázquez-Torres A, Balish E. Macrophages in resistance to candidiasis. Microbiol Mol Biol Rev. 1997;61:170-92.

4. Czop JK, Austen KF. A $\beta$-glucan inhibitable receptor on human monocytes: its identity with the phagocytic receptor for particulate activators of the alternative complement pathway. J Immunol. 1985;134:2588-93.

5. Ross GD, Cain IA, Lachmann PJ. Membrane complement receptor type three $\left(\mathrm{CR}_{3}\right)$ has lectin-like properties analogous to bovine conglutinin and functions as a receptor for zymosan and rabbit erythrocytes as well as a receptor for iC3b. J Immunol. 1985; 134:3307-15.

6. Xia Y, Vetvicka V, Yan J, Hanikyrova M, Mayadas T, Ross GD. The $\beta$-glucan-binding lectin site of mouse CR3 (CD11b/CD18) and its function in generating a primed state of the receptor that mediates cytotoxic activation in response to iC3b-opsonized target cells. J Immunol. 1999;162:2281-90.

7. Brown GD, Gordon S. Immune recognition. A new receptor for $\beta$-glucans. Nature. 2001;413:36-7.

8. Giaimis J, Lombard Y, Fonteneau P, Muller CD, Levy R, Makaya-Kumba M, Lazdins J, Poindron P. Both mannose and $\beta$-glucan receptors are involved in phagocytosis of unopsonized, heat-killed Saccharomyces cerevisiae by murine macrophages. J Leukoc Biol. 1993;54:564-71.

9. Cambi A, Gijzen K, de Vries JM, Torensma R, Joosten B, Adema GJ, Netea MG, Kullberg B-J, Romani L, Figdor CG. The C-type lectin DC-SIGN (CD209) is an antigen-uptake receptor for Candida albicans on dendritic cells. Eur J Immunol. 2003;33:532-8.

10. Taylor PR, Brown GD, Herre J, Williams DL, Willment JA, Gordon S. The role of SIGNR1 and the $\beta$-glucan receptor (Dectin-1) in the nonopsonic recognition of yeast by specific macrophages. J Immunol. 2004;172:1157-62.

11. Netea MG, Van Der Graaf CA, Vonk AG, Verschueren I, Van Der Meer JW, Kullberg BJ. The role of toll-like receptor (TLR) 2 and TLR4 in the host defense against disseminated candidiasis. J Infect Dis. 2002;185:1483-9.

12. Tada H, Nemoto E, Shimauchi H, Watanabe T, Mikami T, Matsumoto T, Ohno N, Tamura H, Shibata K, Akashi S, Miyake K, Sugawara S, Takada H. Saccharomyces cerevisiae- and Candida albicans-derived mannan induced production of tumor necrosis factor $\alpha$ by human monocytes in a CD14- and Toll-like receptor 4-dependent manner. Microbiol Immunol. 2002;46: 503-12.

13. Jouault T, El Abed-El Behi M, Martınez-Esparza M, Breuilh L, Trinel P, Chamaillard M, Trottein F, Poulain D. Specific recognition of Candida albicans by macrophages requires galectin-3 to 
discriminate Saccharomyces cerevisiae and needs association with TLR2 for signaling. J Immunol. 2006;177:4679-87.

14. Brown GD, Taylor PR, Reid DM, Willment JA, Williams DL, Martinez-Pomares L, Wong SY, Gordon S. Dectin-1 is a major $\beta$-glucan receptor on macrophages. J Exp Med. 2002;196:407-12.

15. Taylor PR, Brown GD, Reid DM, Willment JA, Martinez-Pomares L, Gordon S, Wong SYC. The $\beta$-glucan receptor, dectin-1, is predominantly expressed on the surface of cells of the monocyte/macrophage and neutrophil lineages. J Immunol. 2002;169: 3876-82.

16. Lee SJ, Zheng NY, Clavijo M, Nussenzweig MC. Normal host defense during systemic candidiasis in mannose receptor-deficient mice. Infect Immun. 2003;71:437-45.

17. Gantner BN, Simmons RM, Underhill DM. Dectin-1 mediates macrophage recognition of Candida albicans yeast but not filaments. EMBO J. 2005;24:1277-86.

18. Saijo S, Fujikado N, Furuta T, Chung SH, Kotaki H, Seki K, Sudo K, Akira S, Adachi Y, Ohno N, Kinjo T, Nakamura K, Kawakami $\mathrm{K}$, Iwakura Y. Dectin-1 is required for host defense against Pneumocystis carinii but not against Candida albicans. Nat Immunol. 2007;8:39-46.

19. Taylor PR, Tsoni SV, Willment JA, Dennehy KM, Rosas M, Findon H, Haynes K, Steele C, Botto M, Gordon S, Brown GD. Dectin-1 is required for $\beta$-glucan recognition and control of fungal infection. Nat Immunol. 2007;8:31-8.

20. Brown GD, Herre J, Williams DL, Willment JA, Marshall ASJ, Gordon S. Dectin-1 mediates biological effects of $\beta$-glucans. J Exp Med. 2003;197:1119-24.

21. Gantner BN, Simmons RM, Canavera SJ, Akira S, Underhill DM. Collaborative induction of inflammatory responses by dectin-1 and Toll-like receptor 2. J Exp Med. 2003;197:1107-17.

22. McCann F, Carmona E, Puri V, Pagano RE, Limper AH. Macrophage internalization of fungal $\beta$-glucans is not necessary for initiation of related inflammatory responses. Infect Immun. 2005;73:6340-9.

23. Rogers NC, Slack EC, Edwards AD, Nolte MA, Schulz O, Schweighoffer E, Williams DL, Gordon S, Tybulewicz VL, Brown GD, Reis e Sousa C. Syk-dependent cytokine induction by Dectin-1 reveals a novel pattern recognition pathway for $\mathrm{C}$ type lectins. Immunity. 2005;22:507-17.

24. Suram S, Brown GD, Ghosh M, Gordon S, Loper R, Taylor PR, Akira S, Uematsu S, Williams DL, Leslie CC. Regulation of cytosolic phospholipase A2 activation and cyclooxygenase 2 expression in macrophages by the $\beta$-glucan receptor. $\mathrm{J}$ Biol Chem. 2006;281:5506-14.

25. Chamilos G, Ganguly D, Lande R, Gregorio J, Meller S, Goldman WE, Gilliet M, Kontoyiannis DP. Generation of IL-23 producing dendritic cells (DCs) by airborne fungi regulates fungal pathogenicity via the induction of $\mathrm{T}(\mathrm{H})-17$ responses. PLoS One. 2010;5:e12955.

26. Netea MG, Gow NAR, Munro CA, Bates S, Collins C, Ferwerda G, Hobson RP, Bertram G, Hughes HB, Jansen T, Jacobs L, Buurman ET, Gijzen K, Williams DL, Torensma R, McKinnon A, MacCallum DM, Odds FC, Van der Meer JW, Brown AJ, Kullberg BJ. Immune sensing of Candida albicans requires cooperative recognition of mannans and glucans by lectin and Toll-like receptors. J Clin Invest. 2006;116:1642-50.

27. Elomaa O, Kangas M, Sahlberg C, Tuukkanen J, Sormunen R, Liakka A, Thesleff I, Krall G, Tryggvason K. Cloning of a novel bacteria-binding receptor structurally related to scavenger receptors and expressed in a subset of macrophages. Cell. 1995;80:603-9.

28. Thomas CA, Li Y, Kodama T, Suzuki H, Silverstein SC, El Khoury J. Protection from gram-positive infection by macrophage scavenger receptor-dependent phagocytosis. J Exp Med. 2000;191:147-55.
29. Suzuki H, Kurihara Y, Takeya M, Kamada N, Kataoka M, Jishage K, Ueda O, Sakaguchi H, Higashi T, Suzuki T, Takashima Y, Kawabe Y, Cynshi O, Wada Y, Honda M, Kurihara H, Aburatani H, Doi T, Matsumoto A, Azuma S, Noda T, Toyoda Y, Itakura H, Yazaki Y, Kodama T, et al. A role for scavenger receptors in atherosclerosis and susceptibility to infection. Nature. 1997;386: 292-6.

30. Arredouani M, Yang Z, Ning YY, Qin G, Soininen R, Tryggvason K, Kobzik L. The scavenger receptor MARCO is required for lung defense against pneumococcal pneumonia and inhaled particles. J Exp Med. 2004;200:267-72.

31. Bin LH, Nielson LD, Liu X, Mason RJ, Shu HB. Identification of uteroglobin-related protein 1 and macrophage scavenger receptor with collagenous structure as a lung-specific ligand-receptor pair. J Immunol. 2003;171:924-30.

32. Hollifield M, Ghanem EB, de Villiers WJS, Garvy BA. Scavenger receptor A dampens induction of inflammation in response to the fungal pathogen Pneumocystis carinii. Infect Immun. 2007;75:3999-4005.

33. Dushkin MI, Safina AF, Vereschagin EI, Schwartz YS. Carboxymethylated $\beta$-1, 3-glucan inhibits the binding and degradation of acetylated low density lipoproteins in macrophages in vitro and modulates their plasma clearance in vivo. Cell Biochem Funct. 1996;14:209-17.

34. Vereschagin EI, Van Lambalgen AA, Dushkin MI, Schwartz YS, Polyakov L, Heemskerk A, Huisman E, Thijs LG, Van den Bos GC. Soluble glucan protects against endotoxin shock in the rat: the role of the scavenger receptor. Shock. 1998;9:193-8.

35. Rice PJ, Kelly JL, Kogan G, Ensley HE, Kalbfleisch JH, Browder IW, Williams DL. Human monocytes scavenger receptors are pattern recognition receptors for (1-3)- $\beta$-D-glucans. J Leukoc Biol. 2002;72:140-6.

36. Ohtani K, Suzuki Y, Eda S, Kawai T, Kase T, Keshi H, Sakai Y, Fukuoh A, Sakamoto T, Itabe H, Suzutani T, Ogasawara M, Yoshida I, Wakamiya N. The membrane-type collectin CL-P1 is a scavenger receptor on vascular endothelial cells. J Biol Chem. 2001;276:44222-8.

37. Wang R, Chandawarkar RY. Phagocytosis of fungal agents and yeast via macrophage cell surface scavenger receptors. J Surg Res. 2010;164:e273-9.

38. Józefowski S, Sulahian T, Arredouani M, Kobzik L. Role of scavenger receptor MARCO in macrophage responses to $\mathrm{CpG}$ oligodeoxynucleotides. J Leukoc Biol. 2006;80:870-9.

39. Józefowski S, Arredouani M, Sulahian T, Kobzik L. Disparate regulation and function of the class A scavenger receptors SRAI/ II and MARCO. J Immunol. 2005;175:8032-41.

40. Józefowski S, Kobzik L. Scavenger receptor A mediates $\mathrm{H}_{2} \mathrm{O}_{2}$ production and suppression of IL-12 release in murine macrophages. J Leukoc Biol. 2004;76:1066-74.

41. Ariizumi K, Shen GL, Shikano S, Xu S, Ritter R 3rd, Kumamoto T, Edelbaum D, Morita A, Bergstresser PR, Takashima A. Identification of a novel, dendritic cell-associated molecule, dectin-1, by subtractive cDNA cloning. J Biol Chem. 2000;275: 20157-67.

42. Doyle SE, O'Connell RM, Miranda GA, Vaidya SA, Chow EK, Liu PT, Suzuki S, Suzuki N, Modlin RL, Yeh WC, Lane TF, Cheng G. Toll-like receptors induce a phagocytic gene program through p38. J Exp Med. 2004;199:81-90.

43. Daugherty A, Whitman SC, Block AE, Rateri DL. Polymorphism of class A scavenger receptors in C57BL/6 mice. J Lipid Res. 2000;41:1568-77.

44. Zhang H, Yang Y, Steinbrecher UP. Structural requirements for the binding of modified proteins to the scavenger receptor of macrophages. J Biol Chem. 1993;268:5535-42.

45. Brannstrom A, Sankala M, Tryggvason K, Pikkarainen T. Arginine residues in domain $\mathrm{V}$ have a central role for bacteria-binding 
activity of macrophage scavenger receptor MARCO. Biochem Biophys Res Commun. 2002;290:1462-9.

46. Willment JA, Lin HH, Reid DM, Taylor PR, Williams DL, Wong SY, Gordon S, Brown GD. Dectin-1 expression and function are enhanced on alternatively activated and GM-CSF-treated macrophages and are negatively regulated by IL-10, dexamethasone, and lipopolysaccharide. J Immunol. 2003;171:4569-73.

47. Nakamura K, Funakoshi H, Tokunaga F, Nakamura T. Molecular cloning of a mouse scavenger receptor with C-type lectin (SRCL), a novel member of the scavenger receptor family. Biochim Biophys Acta. 2001;1522:53-8.

48. Means TK, Mylonakis E, Tampakakis E, Colvin RA, Seung E, Puckett L, Tai MF, Stewart CR, Pukkila-Worley R, Hickman SE, Moore KJ, Calderwood SB, Hacohen N, Luster AD, El Khoury J. Evolutionarily conserved recognition and innate immunity to fungal pathogens by the scavenger receptors SCARF1 and CD36. J Exp Med. 2009;206:637-53.

49. Petty HR, Worth RG, Todd RF 3rd. Interactions of integrins with their partner proteins in leukocyte membranes. Immunol Res. 2002;25:75-95.

50. Trinel PA, Maes E, Zanetta JP, Delplace F, Coddeville B, Jouault T, Strecker G, Poulain D. Candida albicans phospholipomannan, a new member of the fungal mannose inositol phosphoceramide family. J Biol Chem. 2002;277:37260-71.

51. Hobson RP, Munro CA, Bates S, MacCallum DM, Cutler JE, Heinsbroek SEM, Brown GD, Odds FC, Gow NAR. Loss of cell wall mannosylphosphate in Candida albicans does not influence macrophage recognition. J Biol Chem. 2004;279:39628-35.

52. Zelante T, De Luca A, Bonifazi P, Montagnoli C, Bozza S, Moretti S, Belladonna ML, Vacca C, Conte C, Mosci P, Bistoni F, Puccetti P, Kastelein RA, Kopf M, Romani L. IL-23 and the Th17 pathway promote inflammation and impair antifungal immune resistance. Eur J Immunol. 2007;37:2695-706.

53. Conti HR, Shen F, Nayyar N, Stocum E, Sun JN, Lindemann MJ, Ho AW, Hai JH, Yu JJ, Jung JW, Filler SG, Masso-Welch P,
Edgerton M, Gaffen SL. Th17 cells and IL-17 receptor signaling are essential for mucosal host defense against oral candidiasis. J Exp Med. 2009;206:299-311.

54. Puel A, Cypowyj S, Bustamante J, Wright JF, Liu L, Lim HK, Migaud M, Israel L, Chrabieh M, Audry M, Gumbleton M, Toulon A, Bodemer C, El-Baghdadi J, Whitters M, Paradis T, Brooks J, Collins M, Wolfman NM, Al-Muhsen S, Galicchio M, Abel L, Picard C, Casanova JL. Chronic mucocutaneous candidiasis in humans with inborn errors of interleukin-17 immunity. Science. 2011;332:65-8.

55. Osorio F, LeibundGut-Landmann S, Lochner M, Lahl K, Sparwasser T, Eberl G, Reis e Sousa C. DC activated via dectin-1 convert Treg into IL-17 producers. Eur J Immunol. 2008;38: 3274-81.

56. Dennehy KM, Willment JA, Williams DL, Brown GD. Reciprocal regulation of IL-23 and IL-12 following co-activation of Dectin-1 and TLR signaling pathways. Eur J Immunol. 2009;39: 1379-86.

57. Miyazato A, Nakamura K, Yamamoto N, Mora-Montes HM, Tanaka M, Abe Y, Tanno D, Inden K, Gang X, Ishii K, Takeda K, Akira S, Saijo S, Iwakura Y, Adachi Y, Ohno N, Mitsutake K, Gow NA, Kaku M, Kawakami K. Toll-like receptor 9-dependent activation of myeloid dendritic cells by deoxynucleic acids from Candida albicans. Infect Immun. 2009;77:3056-64.

58. Dillon S, Agrawal S, Banerjee K, Letterio J, Denning TL, Oswald-Richter K, Kasprowicz DJ, Kellar K, Pare J, van Dyke T, Ziegler S, Unutmaz D, Pulendran B. Yeast zymosan, a stimulus for TLR2 and dectin-1, induces regulatory antigen-presenting cells and immunological tolerance. J Clin Invest. 2006;116: 916-28.

59. Fulton WB, Reeves RH, Takeya M, De Maio A. A quantitative trait loci analysis to map genes involved in lipopolysaccharideinduced inflammatory response: identification of macrophage scavenger receptor 1 as a candidate gene. J Immunol. 2006;176: $3767-73$. 